\title{
Simulations of Fungicide Runoff Following Applications for Turfgrass Disease Control
}

\author{
P. Vincelli, Department of Plant Pathology, University of Kentucky, Lexington 40546-0091
}

\begin{abstract}
Vincelli, P. 2004. Simulations of fungicide runoff following applications for turfgrass disease control. Plant Dis. 88:391-396.

Computer simulations of fungicide loading in surface water runoff were conducted with fungicides commonly used in golf course fairways and lawns in Kentucky. For all fungicides, values for degradation half-life and organic carbon partition coefficient were obtained from published sources; other input parameters were selected to simulate conditions typical in local swards. Spray programs were tested using a 21-year period of weather data for Lexington, KY. Predicted amounts of fungicide in runoff were determined, and predicted fungicide concentrations in runoff (mg/liter) were compared with 50\% lethal concentration $\left(\mathrm{LC}_{50}\right)$ values for rainbow trout and Daphnia magna. All simulated chlorothalonil applications produced runoff with concentrations that greatly exceeded the $\mathrm{LC}_{50}$ values for both indicator species. For some applications, concentrations of azoxystrobin, iprodione, and pentachloronitrobenzene exceeded $\mathrm{LC}_{50}$ values of at least one indicator species. Under the conditions simulated, runoff concentrations of metalaxyl, propiconazole, thiophanate methyl, and triadimefon were well below $\mathrm{LC}_{50}$ values of the indicator species. Although actual amounts of fungicide loaded into runoff were relatively low, these simulations suggest that turfgrass applications of fungicides with high intrinsic toxicity to indicator species could pose a risk to populations of primary and secondary consumers in aquatic ecosystems.
\end{abstract}

Additional keywords: TurfPQ, water quality

Turfgrasses under intensive management are often subject to destructive outbreaks of infectious diseases, especially those caused by fungi. While sound turf management practices often reduce the impact of diseases, fungicides can often be an important tool in preventing damaging turf loss and promoting recovery following disease outbreaks. For example, perennial ryegrass is highly susceptible to gray leaf spot caused by Pyricularia grisea (20). While cultural practices can reduce gray leaf spot severity (23), only the judicious and proper use of fungicides can prevent turf loss under the high disease pressure sometimes experienced in Kentucky (21).

Interest in and concern about the environmental fate of pesticides applied to turfgrasses has been increasing steadily for well over a decade. Much attention has focused on golf courses $(1,3,4,12,13$, $18,22)$ where pesticide usage can be relatively intensive on high-maintenance courses. In urban areas, as the area of land maintained as lawns has increased, so has the potential for undesirable water quality

Corresponding author: P. Vincelli

E-Mail: pvincell@uky.edu

Accepted for publication 5 December 2003.

Publication no. D-2004-0202-01R

(C) 2004 The American Phytopathological Society resulting from the use of pesticides on lawns (17). Although pesticide-treated turfgrasses are generally not considered to pose as high a risk to water quality as does cropland or bare soil, significant loading of pesticide can occur from turfgrass into surface runoff, especially when soil antecedent moisture is moderate to high $(1,4)$.

TurfPQ is a deterministic model for simulating runoff of pesticides from turfgrasses (10). This model simulates pesticide runoff by using six input parameters: the soil runoff curve number for average antecedent moisture conditions, the organic carbon partition coefficient $\left(K_{\mathrm{oc}}\right)$ and half-life of the pesticide of interest, the organic carbon content of the turf, and daily temperature and rainfall. In comparisons of TurfPQ predictions against 52 runoff events for herbicides or insecticides from turfgrass (10), the model had a tendency to somewhat overestimate pesticide runoff amounts, particularly for those with a high $K_{\text {oc }}$. However, the magnitude of overestimation was generally acceptable, with predicted values averaging $1.4 \times$ the mean of observed values, and an $R^{2}=0.65$ (10). The TurfPQ model has been used to simulate runoff risks of pesticides commonly used on golf courses in the northeastern United States (11).

The objective of this test was to use the TurfPQ simulation model to explore whether fungicide applications recommended for control of common turfgrass diseases in Kentucky could pose a risk to aquatic ecosystems through loading into surface runoff.

\section{MATERIALS AND METHODS}

General simulation conditions. Values for the runoff curve number for average antecedent moisture conditions ( $\mathrm{CN} 2$ values) and organic carbon (OC) in foliage and thatch were selected from published values that approximated turfgrass conditions in central Kentucky $(8,10)$. Daily data for temperature and precipitation during 1981 to 2001 were obtained from the University of Kentucky Agricultural Weather Center. All simulations were conducted using the same weather data input file; no supplemental irrigation was assumed. For all simulations of cool-season grasses, active growth was assumed from April through October; simulations with zoysiagrass assumed active growth from May through September. For some simulation sets, simulations were conducted for soils in hydrologic group B and group C (moderate and slow infiltration rates, respectively) (6); otherwise, simulations were conducted using soils in hydrologic group B. Unless otherwise specified, coverage of soil by turfgrass was assumed to be $>75 \%$ (soil not covered by turfgrass is assumed bare) (10). Fungicide parameters used in simulations and in analyses (Table 1) were taken from published sources $(2,9,11)$ and the following sites on the worldwide web: EXTOXNET (Extension Toxicology Network), USDA ARS Pesticide Database, and Oregon State University Pesticide Properties Database.

Output values for surface runoff $(\mathrm{mm} / \mathrm{ha})$ and fungicide mass in runoff ( $\mathrm{g} / \mathrm{ha}$ ) were used to calculate fungicide in runoff as a percentage of that applied and fungicide concentration in runoff water. The latter data were compared with $50 \%$ lethal concentration $\left(\mathrm{LC}_{50}\right)$ values for water flea (Daphnia magna) and rainbow trout (Salmo gairdneri) (Table 1) $(2,19)$, which serve as indicator species for primary and secondary consumers in aquatic ecosystems, respectively.

Simulation set 1 (SS1). Simulations were conducted of creeping bentgrass fairways with a 16-mm mowing height. The CN2 and OC values used were 55 and $3,600 \mathrm{~kg} / \mathrm{ha}$, which assumed a 2-mm thatch layer. Four fungicide spray programs designed to give protection against dollar spot disease (caused by Sclerotinia homoeocarpa) were evaluated: triadimefon 
applied at $760 \mathrm{~g} / \mathrm{ha}$ on 15 May and 12 June, propiconazole at $496 \mathrm{~g} / \mathrm{ha}$ on the same dates, and chlorothalonil applied from 15 May through 26 June weekly at $4,786 \mathrm{~g} / \mathrm{ha}$ or biweekly at $8,038 \mathrm{~g} / \mathrm{ha}$.

Simulation set 2 (SS2). This set simulated perennial ryegrass fairways with a 19.2-mm mowing height having $1,615 \mathrm{~kg}$ of OC per ha (no thatch). CN2 values used were 61 and 74 for soils in hydrologic groups $\mathrm{B}$ and $\mathrm{C}$, respectively. Spray programs for controlling gray leaf spot (caused by Pyricularia oryzae) were as follows: propiconazole applied at $496 \mathrm{~g} / \mathrm{ha}$ on 3 and 17 August; chlorothalonil applied at $8,038 \mathrm{~g} / \mathrm{ha}$ on 3 and 17 August; azoxystrobin applied at $608 \mathrm{~g} / \mathrm{ha}$ on 3 August; azoxystrobin applied at $304 \mathrm{~g} / \mathrm{ha}$ on $3 \mathrm{Au}-$ gust (soil hydrologic group B only); and simulations of thiophanate methyl applied at $9,150 \mathrm{~g} / \mathrm{ha}, 6,100 \mathrm{~g} / \mathrm{ha}$, or $3,050 \mathrm{~g} / \mathrm{ha}$ on 3 and 17 August.

Simulation set 3 (SS3). To simulate fungicide runoff from a fairway being established from seed into cultivated soil, simulations were conducted on turf with an average mowing height of $22.2 \mathrm{~mm}$ and poor $(<50 \%)$ soil coverage by vegetation. The CN2 and OC values used were 79 and $2,886 \mathrm{~kg}$ of OC per ha. Applications of metalaxyl at 337 or $674 \mathrm{~g} / \mathrm{ha}$ were made on 1 September to simulate application of a fungicide soon after emergence to control damping-off and cottony blight, caused by Pythium aphanidermatum and other Pythium species.

Simulation set 4 (SS4). This set simulated conditions on a zoysiagrass fairway where applications were made for control of large patch (caused by Rhizoctonia solani). The mowing height simulated was $19.2 \mathrm{~mm}$ and the $\mathrm{CN} 2$ and $\mathrm{OC}$ values were 55 and 7,215 kg/ha (assuming a 5-mm thatch), respectively. Fungicide programs simulated were as follows: azoxystrobin applied at $608 \mathrm{~g} / \mathrm{ha}$; pentachloronitrobenzene $(\mathrm{PCNB})$ applied at $36,620 \mathrm{~kg} / \mathrm{ha}$; and triadimefon applied at $1,523 \mathrm{~g} / \mathrm{ha}$. All applications were made on 20 September and 25 March.

Simulation set 5 (SS5). For all lawn simulations, the mowing height was 64

Table 1. Fungicide parameters used in simulations of fungicide loading in surface runoff following applications to control turfgrass diseases

\begin{tabular}{|c|c|c|c|c|}
\hline \multirow[b]{2}{*}{ Fungicide } & \multirow[b]{2}{*}{ Half-life (days) } & \multirow[b]{2}{*}{$K_{\mathrm{oc}}\left(\mathrm{cm}^{3} / \mathrm{g}\right)$} & \multicolumn{2}{|c|}{$\mathrm{LC}_{50}(\mathrm{mg} / \text { liter })^{\mathrm{a}}$} \\
\hline & & & Daphnia magna & Rainbow trout \\
\hline Azoxystrobin & 56 & 500 & 0.259 & 0.47 \\
\hline Chlorothalonil & 30 & 1,380 & 0.070 & 0.049 \\
\hline Iprodione & 14 & 700 & 0.25 & 4.1 \\
\hline Metalaxyl & 8 & 50 & $>28$ & $>100$ \\
\hline Pentachloronitrobenzene & 21 & 5,000 & 0.77 & 0.55 \\
\hline Propiconazole & 29 & 650 & 4.8 & 5.3 \\
\hline Thiophanate-methyl & 10 & 1,830 & 20.2 & 7.8 \\
\hline Triadimefon & 26 & 300 & 11.3 & 17.4 \\
\hline
\end{tabular}

Table 2. Mean monthly runoff volumes from simulations of turfgrass ecosystems in Lexington, KY

\begin{tabular}{llcc}
\hline & \multicolumn{1}{c}{ Host } & \multicolumn{2}{c}{ Predicted runoff $\left(\times \mathbf{1 0}^{\mathbf{3}}\right.$ liter/ha $)$} \\
\cline { 3 - 4 } Simulation set (SS) & Group B & Group C \\
\hline SS1, SS6 & Creeping bentgrass fairway & 11.3 & 30.5 \\
SS2, SS6 & Perennial ryegrass fairway & 18.8 & 52.7 \\
SS3 & New seeding, cool-season grass & 78.3 & NT $^{\mathbf{b}}$ \\
SS4 & Zoysiagrass fairway & 11.9 & $\mathrm{NT}$ \\
SS5 & Tall fescue lawn & 14.7 & NT \\
SS5 & Kentucky bluegrass lawn & 8.6 & NT \\
\hline
\end{tabular}

${ }^{\text {a }}$ Group B and C refer to soil hydrologic group B and C, respectively (6).

${ }^{\mathrm{b}} \mathrm{NT}=$ not tested.

Table 3. Fungicide loading in surface runoff in simulated applications to control dollar spot on creeping bentgrass fairways (simulation set 1$)^{\mathrm{a}}$

\begin{tabular}{lcc}
\hline Fungicide, application rate, and schedule & $\begin{array}{c}\text { Mean amount of fungicide } \\
\text { in runoff (g/ha/year) } \\
\text { (\% of that applied) }\end{array}$ & $\begin{array}{c}\text { Mean peak } \\
\text { concentration } \\
\text { (mg/liter) }\end{array}$ \\
\hline Triadimefon, 760 g/ha, 15 May and 12 June & $5.5(0.4)$ & 0.335 \\
Propiconazole, 496 g/ha, 15 May and 5 June & $3.1(0.3)$ & 0.142 \\
Chlorothalonil, 4,786 g/ha, weekly 15 May to 26 June & $87.0(0.3)$ & 2.622 \\
Chlorothalonil, 8,038 g/ha, biweekly from 15 May to 26 June & $82.5(0.3)$ & 2.168 \\
\hline
\end{tabular}

${ }^{a}$ All simulations were conducted assuming the soil was in hydrologic group B.

${ }^{\mathrm{b}}$ For each month, the mean fungicide concentration in runoff was calculated over 21 years of simulations. This column reports the highest of those monthly means. $\mathrm{mm}$ and fungicides were applied on 1 June, 1 July, and 1 August. Simulations of disease control in lawns were mostly conducted in tall fescue lawns $(\mathrm{CN} 2$ value of 58 , OC of $4,160 \mathrm{~kg} / \mathrm{ha}$, and no thatch), in which fungicides may be applied to control brown patch caused by Rhizoctonia solani. Fungicide programs tested were as follows: propiconazole applied at $992 \mathrm{~g} / \mathrm{ha}$, triadimefon applied at $763 \mathrm{~g} / \mathrm{ha}$, and azoxystrobin applied at $305 \mathrm{~g} / \mathrm{ha}$ or $610 \mathrm{~g} / \mathrm{ha}$. One simulation was conducted in Kentucky bluegrass with parameters as follows: CN2 value of 52 and OC of 11,272 $\mathrm{kg} / \mathrm{ha}$ (assumes a 6-mm thatch). In Kentucky bluegrass, the fungicide applied was azoxystrobin at $610 \mathrm{~g} / \mathrm{ha}$ that was intended to control summer patch caused by Magnaporthe poae.

Simulation set 6 (SS6). This set simulated fungicide applications targeting pink snow mold and Microdochium patch, both caused by Microdochium nivale. Simulations of perennial ryegrass fairways assumed a 19.2-mm mowing height having $1,615 \mathrm{~kg}$ of OC per ha (no thatch) and $\mathrm{CN} 2$ values used were 61 and 74 for soils in hydrologic groups B and C, respectively. Fungicides were applied on 10 December at the following rates: iprodione applied at 3,052 $\mathrm{g} / \mathrm{ha}$; chlorothalonil applied at 12,588 $\mathrm{g} / \mathrm{ha}$; and PCNB applied at 18,310 $\mathrm{g} / \mathrm{ha}$. Simulations of creeping bentgrass fairways assumed a 16-mm mowing height having $3,600 \mathrm{~kg}$ of $\mathrm{OC}$ per ha (2-mm thatch); and $\mathrm{CN} 2$ values used were 55 and 67 for soils in hydrologic groups B and C, respectively. Fungicides were applied on 5 November and 15 February at the following rates: iprodione at $3,052 \mathrm{~g} / \mathrm{ha}$; and chlorothalonil at $12,588 \mathrm{~g} / \mathrm{ha}$.

\section{RESULTS}

Volume of surface runoff. In simulations of runoff from established turfs on soils in hydrologic group B, mean monthly volumes of surface runoff ranged from 8,600 to 18,800 liter/ha (Table 2). Runoff values from grasses that were rhizomatous or stoloniferous (creeping bentgrass, Kentucky bluegrass, or zoysiagrass) were less than runoff values from bunchgrasses (perennial ryegrass or tall fescue). Simulated runoff volumes were more than twice as high from soils in hydrologic group $\mathrm{C}$ than they were from group B. Runoff volumes were more than four times higher in simulations of new seedings than they were in established turfs.

Mass of fungicide in runoff. Annual fungicide loads in simulated runoff from soils in hydrologic group B ranged from 3.1 to $120.9 \mathrm{~g} / \mathrm{ha}$ (Tables 3-8). In all simulations on such soils, fungicide loads from established turfs represented no more than $1.1 \%$ of that applied and usually less than $1.0 \%$. In the case of simulated metalaxyl application to a newly established fairway (soil in hydrologic group B), the load was $3.7 \%$ of that applied (Table 5). Fungicide 
loading was more than twice as high in runoff from soils in hydrologic group $C$ compared with soils from group B (Tables 4 and 8). Not surprisingly, in cases where simulations were conducted with fungicides at several rates, fungicide loading in runoff was proportional to application rate (Tables 4, 5, and 7). At an equivalent rate of application, simulated loads of azoxystrobin from Kentucky bluegrass, a thatch-forming grass, was less than onehalf of that observed from tall fescue, a bunchgrass (Table 7).

Potential toxicity of runoff to aquatic ecosystems. In all simulations, concentrations of propiconazole, triadimefon, thiophanate methyl, and metalaxyl in runoff were well below $\mathrm{LC}_{50}$ values for rainbow trout and Daphnia magna (Tables 37; Fig. 1). Concentrations of propiconazole, triadimefon, thiophanate methyl, and metalaxyl never exceeded 6, 3, 22, and $1 \%$, respectively, of their $\mathrm{LC}_{50}$ values for rainbow trout or D. magna.

All simulated chlorothalonil applications to fairways produced runoff with concentrations that greatly exceeded $\mathrm{LC}_{50}$ values of both indicator species. At its mean peak concentration, chlorothalonil concentrations exceeded $\mathrm{LC}_{50}$ values of indicator species by $\geq 31$-fold, $\geq 43$-fold, 30 -fold, and $\geq 21$-fold for SS1, SS2, perennial ryegrass in SS6, and creeping bentgrass in SS6, respectively (Tables 3, 4 and 8; Figs. 1 and 2). Mean monthly chlorothalonil concentrations predicted for runoff exceeded $\mathrm{LC}_{50}$ values of both indicator species for the following durations (mean monthly concentration data not shown): 8 months in SS1; 5 months in SS2 and SS6 in both soil hydrologic groups; 4 months in perennial ryegrass simulations; and 8 months in creeping bentgrass simulations.

Simulated concentrations of azoxystrobin, iprodione, and PCNB in runoff exceeded $\mathrm{LC}_{50}$ values of at least one indicator species in several instances. At the $608 \mathrm{~g} / \mathrm{ha}$ application rate, azoxystrobin exceeded the $\mathrm{LC}_{50}$ for $D$. magna for 1 month in both soil groups in SS2 (Table 4; Fig. 1) and in the tall fescue simulation in SS5 (Table 7; mean monthly concentration data not shown) but not in SS4 or in the Kentucky bluegrass simulation in SS5 (Tables 6 and 7; mean monthly concentration data not shown). In SS6, iprodione exceeded the $\mathrm{LC}_{50}$ for $D$. magna for 1 month in both soil groups in perennial ryegrass and for 2 months in creeping bentgrass (Table 8; Fig. 2; mean monthly concentration data for creeping bentgrass

not shown). PCNB exceeded the $\mathrm{LC}_{50}$ of rainbow trout for 1 month in SS4 (Table 6; mean monthly concentration data not shown) and in $\mathrm{SS} 6, \mathrm{LC}_{50}$ values for $D$. magna and rainbow trout were exceeded for 1 and 2 months, respectively in both soil groups (Table 8; Fig. 2; mean monthly concentration data for creeping bentgrass not shown).

Table 5. Fungicide loading in surface runoff in simulated applications to control Pythium dampingoff and cottony blight on newly established fairways of a cool-season grass (simulation set 3$)^{\text {a }}$

\begin{tabular}{|c|c|c|}
\hline Fungicide and application rate ${ }^{\mathrm{b}}$ & $\begin{array}{c}\text { Mean amount of fungicide } \\
\text { in runoff }(\mathrm{g} / \mathrm{ha} / \mathrm{year}) \\
\text { (\% of that applied) }\end{array}$ & $\begin{array}{l}\text { Mean peak concentration } \\
\left(\mathrm{mg} /{\text { liter })^{\mathrm{c}}}\right.\end{array}$ \\
\hline Metalaxyl, $674 \mathrm{~g} / \mathrm{ha}$ & $24.8(3.7)$ & 0.232 \\
\hline Metalaxyl, $337 \mathrm{~g} / \mathrm{ha}$ & $12.4(3.7)$ & 0.116 \\
\hline
\end{tabular}

a All simulations were conducted assuming the soil was in hydrologic group B.

b Applied 1 September.

${ }^{\mathrm{c}}$ For each month, the mean fungicide concentration in runoff was calculated over 21 years of simulations. This column reports the highest of those monthly means.

Table 6. Fungicide loading in surface runoff in simulated applications to control large patch on zoysia fairways (simulation set 4$)^{\mathrm{a}}$

\begin{tabular}{lcc}
\hline Fungicide and application rate $^{\mathbf{b}}$ & $\begin{array}{c}\text { Mean amount of fungicide } \\
\text { in runoff (g/ha/year) } \\
\text { (\% of that applied) }\end{array}$ & $\begin{array}{c}\text { Mean peak concentration } \\
\text { (mg/liter) }^{\mathbf{c}}\end{array}$ \\
\hline Azoxystrobin, 608 g/ha & $3.6(0.3)$ & 0.104 \\
Pentachloronitrobenzene, 36,620 g/ha & $14.5(0.02)$ & 0.647 \\
Triadimefon, 1,523 g/ha & $5.7(0.2)$ & 0.283 \\
\hline
\end{tabular}

a All simulations were conducted assuming the soil was in hydrologic group B.

${ }^{\mathrm{b}}$ Applied 20 September and 25 March.

${ }^{\mathrm{c}}$ For each month, the mean fungicide concentration in runoff was calculated over 21 years of simulations. This column reports the highest of those monthly means.

Table 7. Fungicide loading in surface runoff in simulated applications to control diseases of tall fescue and Kentucky bluegrass lawns (simulation set 5$)^{\mathrm{a}}$

\begin{tabular}{lcc}
\hline Fungicide, application rate and host & $\begin{array}{c}\text { Mean amount of fungicide } \\
\text { in runoff (g/ha/year) } \\
\text { (\% of that applied) }\end{array}$ & $\begin{array}{c}\text { Mean peak concen- } \\
\text { tration } \\
\text { (mg/liter) }\end{array}$ \\
\hline Propiconazole, $992 \mathrm{~g} / \mathrm{ha}$, tall fescue & $14.7(0.2)$ & 0.261 \\
Triadimefon, 763 g/ha, tall fescue & $12.9(0.1)$ & 0.266 \\
Azoxystrobin, 608 g/ha, tall fescue & $14.6(0.8)$ & 0.270 \\
Azoxystrobin, 305 g/ha, tall fescue & $7.3(0.8)$ & 0.134 \\
Azoxystrobin, 608 g/ha, Kentucky bluegrass & $5.9(0.3)$ & 0.141 \\
\hline
\end{tabular}

a All simulations were conducted assuming the soil was in hydrologic group B.

${ }^{\mathrm{b}}$ Applications made 1 June, 1 July, and 1 August.

${ }^{\mathrm{c}}$ For each month, the mean fungicide concentration in runoff was calculated over 21 years of simulations. This column reports the highest of those monthly means.

Table 4. Fungicide loading in surface runoff in simulated applications to control gray leaf spot on perennial ryegrass fairways (simulation set 2)

\begin{tabular}{|c|c|c|c|c|}
\hline \multirow[b]{2}{*}{ Fungicide, application rate, and schedule } & \multicolumn{2}{|c|}{$\begin{array}{c}\text { Mean amount of fungicide in runoff ( } \mathrm{g} / \mathrm{ha} / \mathrm{year}) \\
\text { (\% of that applied) }\end{array}$} & \multicolumn{2}{|c|}{$\begin{array}{c}\text { Mean peak concentration } \\
(\mathrm{mg} / \text { /liter })^{\mathrm{a}}\end{array}$} \\
\hline & Group B $^{\mathbf{b}}$ & Group C & Group B & Group C \\
\hline Propiconazole, $496 \mathrm{~g} / \mathrm{ha}, 3$ and 17 August & $8.5(0.9)$ & $28.4(2.9)$ & 0.307 & 0.269 \\
\hline Chlorothalonil, $8038 \mathrm{~g} / \mathrm{ha}, 3$ and 17 August & $108.8(0.7)$ & $331.0(2.1)$ & 3.110 & 3.040 \\
\hline Thiophanate-methyl, $9,150 \mathrm{~g} / \mathrm{ha}, 3$ and 17 August & $36.1(0.2)$ & $121.3(0.7)$ & 1.617 & 1.719 \\
\hline Thiophanate-methyl, 6,100 g/ha, 3 and 17 August & $24.0(0.2)$ & $80.9(0.7)$ & 1.077 & 1.146 \\
\hline Thiophanate-methyl, $3,050 \mathrm{~g} / \mathrm{ha}, 3$ and 17 August & $12.0(0.2)$ & $40.4(0.7)$ & 0.539 & 0.573 \\
\hline Azoxystrobin, $608 \mathrm{~g} / \mathrm{ha}, 3$ August & $6.9(1.1)$ & 23.7 (3.9) & 0.272 & 0.293 \\
\hline Azoxystrobin, $304 \mathrm{~g} / \mathrm{ha}, 3$ August & $3.4(1.1)$ & $\mathrm{NT}^{\mathrm{c}}$ & 0.136 & NT \\
\hline
\end{tabular}

${ }^{a}$ For each month, the mean fungicide concentration in runoff was calculated over 21 years of simulations. These columns report the highest of those monthly means.

${ }^{\mathrm{b}}$ Group B and C refer to soil hydrologic group B and C, respectively.

${ }^{\mathrm{c}} \mathrm{NT}=$ not tested. 


\section{DISCUSSION}

The computer simulations reported here suggest that certain applications of fungicides on turfgrass could pose a risk to populations of primary and secondary consumers in aquatic ecosystems. In these simulations, the proportion of applied fungicide that loaded into surface runoff typically was low, consistent with a number of field studies of pesticide runoff from turf $(8,16,22)$. However, fungicides with high intrinsic toxicity to rainbow trout and $D$. magna were present in simulated runoff from fairways and lawns at concentrations that exceeded $\mathrm{LC}_{50}$ values of these indicator species, particularly when applied at high rates. While these statements refer to predicted concentrations in runoff and not in receiving waters, it seems feasible that runoff with levels exceeding $\mathrm{LC}_{50} \mathrm{~s}$ of the indicator species could pose some ecological risk, especially when runoff volume is high.

The most striking case was chlorothalonil. In all simulations, the concentrations of this fungicide in runoff greatly exceeded $\mathrm{LC}_{50}$ values of the indicator species for months following application, and volumes of such runoff were substantial. Chlorothalonil is applied at relatively high rates for turfgrass disease control and is very highly toxic to certain aquatic organisms. Thus, applications of this fungicide would appear to pose the greatest risk to water quality of those fungicides simulated in this study. Indeed, concern over risks to water quality was a key reason for recently imposed restrictions on chlorothalonil usage in the United States, such as reduced application rates and maximum allowable amounts per season (7). The simulation results reported here are consistent with those concerns. The results reported here also raise concerns about water quality risks following treatment of turf with azoxystrobin, iprodione, or PCNB, which, along with chlorothalonil, were the most toxic fungicides to the indicator species in these simulations (Table 1). Haith and Rossi (11) reported similar results with these fungicides in simulations designed to investigate general factors that influence pesticide runoff on golf courses in the northeastern United States. This study differs from previous work in that simulation conditions
Thiophanate methyl runoff, applied at $9150 \mathrm{~g}$ ai/ha, 3 Aug and 17 Aug

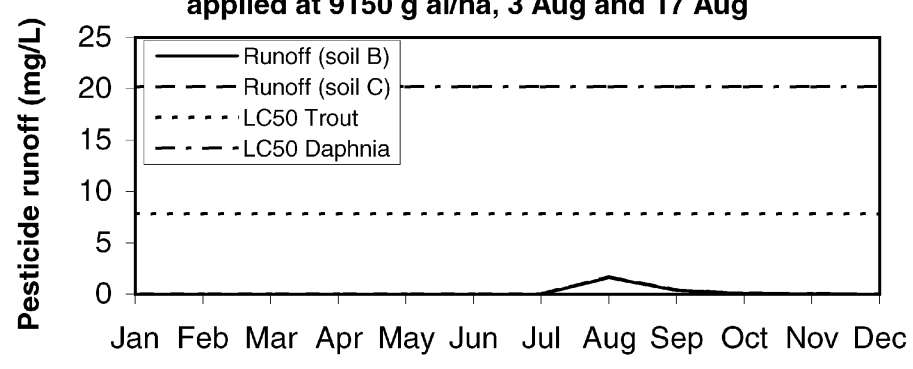

Propiconazole runoff,

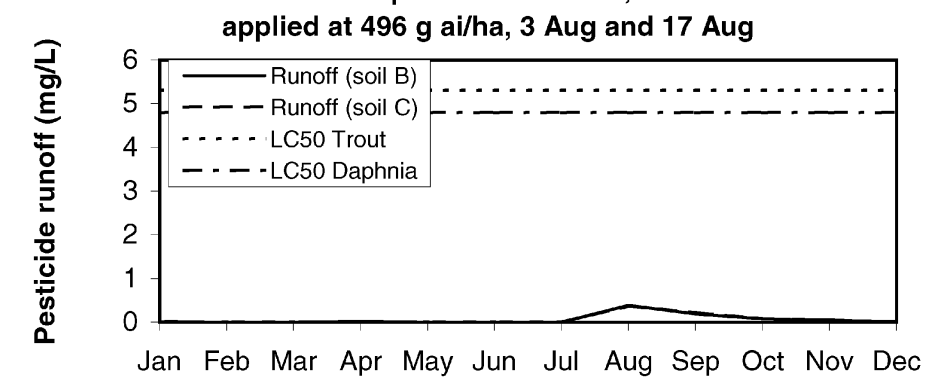

Azoxystrobin runoff,

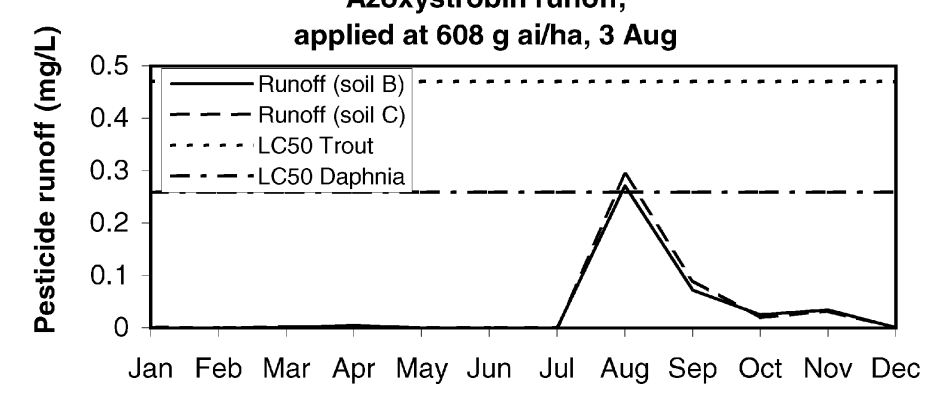

Chlorothalonil runoff,

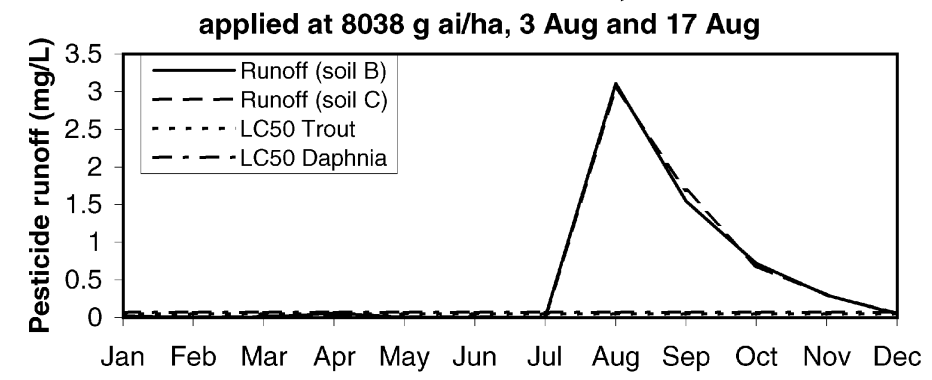

Fig. 1. Mean monthly concentration of four fungicides in surface runoff over 21 years in selected simulations of preventive applications to control gray leaf spot of perennial ryegrass (simulation set 2). Soil $B$ and $C$ represent turf growing on soils in hydrologic group $B$ and $C$, respectively. $\mathrm{LC}_{50}(50 \%$ lethal concentration) values for rainbow trout and Daphnia magna are indicated.

Table 8. Fungicide loading in surface runoff in simulated applications to control pink snow mold and Microdochium patch on fairways of perennial ryegrass or creeping bentgrass (simulation set 6 )

\begin{tabular}{|c|c|c|c|c|}
\hline \multirow[b]{2}{*}{ Fungicide, application rate, schedule, and host ${ }^{\mathrm{a}}$} & \multicolumn{2}{|c|}{$\begin{array}{c}\text { Mean amount of fungicide in runoff } \\
\text { (g/ha/year) }(\% \text { of that applied })\end{array}$} & \multicolumn{2}{|c|}{$\begin{array}{c}\text { Mean peak concentration } \\
(\mathrm{mg} / \text { /liter })^{\mathrm{a}}\end{array}$} \\
\hline & Group B ${ }^{b}$ & Group C & Group B & Group C \\
\hline Iprodione, $3,052 \mathrm{~g} / \mathrm{ha}, 10$ December, perennial ryegrass & $24.0(0.8)$ & $57.3(1.9)$ & 0.484 & 0.506 \\
\hline Chlorothalonil, $12,588 \mathrm{~g} / \mathrm{ha}, 10$ December, perennial ryegrass & $120.9(1.0)$ & $303.4(2.4)$ & 2.075 & 2.085 \\
\hline Pentachloronitrobenzene, $18,310 \mathrm{~g} / \mathrm{ha}, 10$ December, perennial ryegrass & $61.4(0.3)$ & $148.4(0.8)$ & 1.070 & 1.036 \\
\hline Iprodione, $3,052 \mathrm{~g} / \mathrm{ha}, 5$ November and 15 February, creeping bentgrass & $7.7(0.1)$ & $29.5(0.5)$ & 0.479 & 0.482 \\
\hline Chlorothalonil, $12,588 \mathrm{~g} / \mathrm{ha}, 5$ November and 15 February, creeping bentgrass & $46.5(0.2)$ & $145.8(0.6)$ & 1.541 & 1.500 \\
\hline
\end{tabular}

${ }^{a}$ For each month, the mean fungicide concentration in runoff was calculated over 21 years of simulations. These columns report the highest of those monthly means.

${ }^{\mathrm{b}}$ Group B and C refer to soil hydrologic group B and C, respectively. 
were selected to represent specific fungicidal active ingredients, rates, and application schedules recommended for control of selected, important turfgrass diseases common in Kentucky and surrounding states. It is significant that results of both studies were convergent with respect to concern about water-quality risks from fungicides with high toxicity to the indicator species.

On the basis of the results reported here, it would be wise for turfgrass managers to reduce the use of fungicides that pose the highest risk to surface waters, especially under conditions that may have a significant risk of surface runoff. In practice, many factors enter into the decisionmaking process with respect to which fungicides to use and when, factors such as the risk of other diseases, spectrum of disease control provided, potential risks of phytotoxicity under prevailing conditions, cost, availability, compatibility with other chemical applications, and etc. Because toxicity to aquatic ecosystems may not always be a priority in selecting fungicides, a prudent course of action would be to educate turf managers about potential risks to water quality from fungicides and tactics for reducing such risks. Such tactics are varied and include: maintenance of untreated filter strips of taller grass or buffer strips of naturalized vegetation along streams, ponds, and lakes; avoiding applications soon before heavy rainfall, or onto swards with saturated or frozen soils; proper scheduling and application of irrigation; use of care when applying fungicides during seeding and establishment; and construction of "created wetlands" to receive runoff from turf areas $(1,4,14,15)$.

The simulations reported here assumed that no irrigation was applied, although swards that receive fungicide for disease control are also likely to be managed with high levels of maintenance, including application of irrigation as needed. It should be possible to incorporate simulated irrigation events into the TurfPQ model by inserting reasonable values for irrigation volume directly into the rainfall column of the weather data input file, although I chose to run simulations without such manipulations of the raw input data. However, the inclusion of irrigation in these simulations almost certainly would have resulted in even higher estimates of fungicide loading than those reported here. Proper irrigation practices do not induce significant amounts of surface runoff, although excessive irrigation certainly can. The principal mechanism by which irrigation can increase the risk of fungicide runoff is by increasing the antecedent moisture of the soil. This can result in significantly greater volumes of surface runoff and consequently greater fungicide loading if substantial rainfall occurs sometime after irrigation $(4,8)$, such as when unexpected storms occur following irriga- tion. Turf managers implementing the spray programs evaluated here would be likely to apply irrigation during dry periods, hence increasing the risk of fungicide runoff.

Fungicide loads were more than three times higher in simulations of a newly established sward than in any established turf. Simulations on new swards were conducted only with metalaxyl, a commonly recommended fungicide on new seedings of cool-season turfgrasses in Kentucky. Metalaxyl has very short half-life in turfgrass ecosystems (9), the shortest of those included in this study. It seems reasonable to speculate that fungicide loading would be even greater on newly established turfs when more persistent fungicides are applied. The risk of fungicide runoff from newly established turf could even be substantially higher than that reported here, in which no irrigation was assumed. Although my simulations assumed no irrigation, newly established turf needs frequent replenishment of soil moisture from either irrigation or natural rainfall because of its limited root system and sensitivity to even modest drought stress. As discussed previously, this would increase the risk of fungicide loading should a significant rainfall event occur. Thus, new seedings and newly established turfs should be managed with particular care in ways to reduce the risks of fungicides in runoff.

Not surprisingly, substantially more fungicide loading in runoff occurred on soils in hydrologic group $\mathrm{C}$ than it did in group
PCNB runoff, applied at $18,310 \mathrm{~g}$ ai/ha, $10 \mathrm{Dec}$

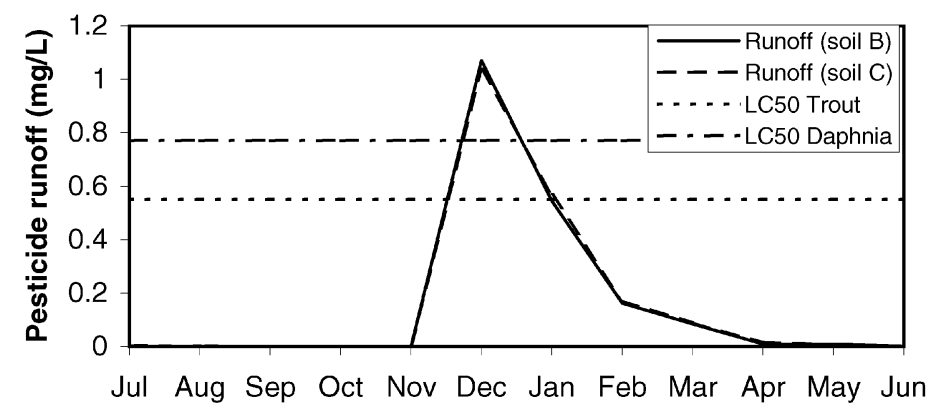

Iprodione runoff, applied at $3052 \mathrm{~g}$ ai/ha, $10 \mathrm{Dec}$

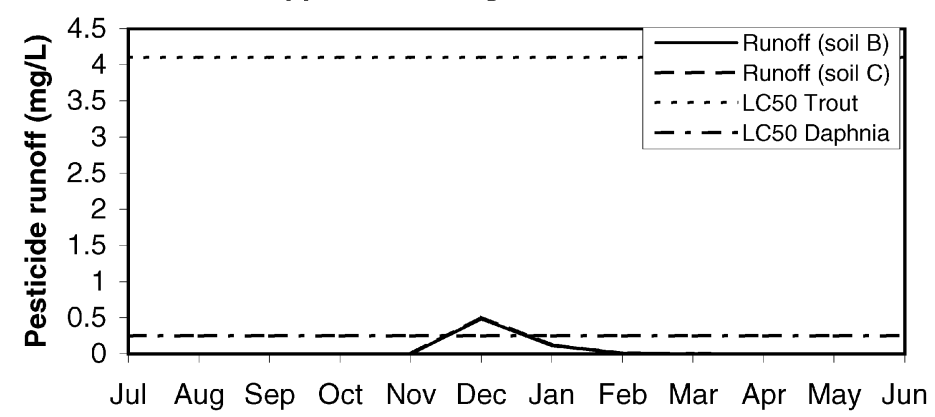

Chlorothalonil runoff,

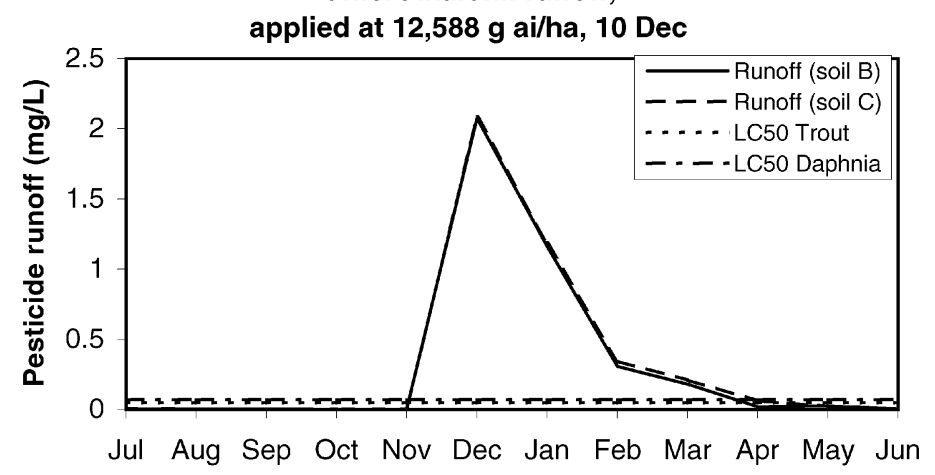

Fig. 2. Mean monthly concentration of three fungicides in surface runoff over 21 years in selected simulations of preventive applications to control pink snow mold and Microdochium patch of perennial ryegrass (simulation set 6). Soil B and C represent turf growing on soils in hydrologic group B and $\mathrm{C}$, respectively. $\mathrm{LC}_{50}(50 \%$ lethal concentration) values for rainbow trout and Daphnia magna are indicated. 
B. It was interesting, however, that simulated concentrations of fungicide in runoff were similar for both soil groups (Tables 4 and 8). In these simulations, increased runoff volume from group C soils approximately compensated for increased loading of fungicide into runoff, resulting in similar fungicide concentrations in both cases. Similarly, Evans et al. (8) found that diazinon loading in runoff from turfgrass plots increased proportionately with increasing runoff volume, resulting in diazinon concentrations that were similar among plots differing in runoff volume.

The observation of substantially reduced fungicide loading in runoff from a turfgrass sward with thatch as compared to one without thatch is consistent with research showing that the presence of a thatch greatly increases sorbtion of pesticides $(5,13)$.

\section{ACKNOWLEDGMENTS}

I extend my thanks to Pat Yancey for data entry and clerical support, Ed Dixon for assistance with data analysis and preparation of figures, Doug Haith for providing the TurfPQ software and periodic technical advice, Frank Rossi for providing an unpublished manuscript, and John R. Hartman for providing helpful comments on a previous version of the manuscript.

\section{LITERATURE CITED}

1. Baird, J. H., Basta, N. T., Huhnke, R. L., Johnson, G. V., Payton, M. E., Storm, D. E., Wilson, C. A., Smolen, M. D., Martin, D. L., and Cole, J. T. 2000. Best management practices to reduce pesticide and nutrient runoff from turf. Pages 268-293 in: Fate and Management of Turfgrass Chemicals, J. M. Clark and M. P. Kenna, eds. ASC Symposium Se- ries 743, American Chemical Society, Washington DC.

2. Bartlett, D. W., Clough, J. M., Godwin, J. R., Hall, A. A., Hamer, M., and Parr-Dobrzanski, B. 2002. The strobilurin fungicides. Pest Manage. Sci. 58:649-662.

3. Cohen, S., Svrjcek, A., Durborow, T., and Barnes, N. L. 1999. Water quality impacts by golf courses. J. Environ. Qual. 28:798-809.

4. Cole, J. T., Baird, J. H., Basta, N. T., Huhnke, R. L., Storm, D. E., Johnson, G. V., Payton, M. E., Smolen, M. D., Martin, D. L., and Cole, J. C. 1997. Influence of buffers on pesticide and nutrient runoff from bermudagrass turf. J. Environ. Qual. 26:1589-1598.

5. Dell, C. J., Throssell, C. S., Bischoff, M., and Turco, R. F. 1994. Estimation of sorbtion coefficients for fungicides in soil and thatch. J. Environ. Qual. 23:92-96.

6. Engineering Staff. 1993. National Engineering Handbook. Part 630, Section 4, Chapter 7. USDA-NRCS, Engineering Division. U.S. Gov. Printing Office, Washington, DC

7. EPA. 1999. Reregistration Eligibility Decision (RED): Chlorothalonil. EPA 738-R-99-004. U. S. Environmental Protection Agency.

8. Evans, J. R., Edwards, D. R., Workman, S. R., and Williams, R. M. 1998. Response of runoff diazinon concentration to formulation and post-application irrigation. Trans. Am. Soc. Agric. Eng. 41:1323-1329.

9. Gardner, D. S., and Branham, B. E. 2001. Effect of turfgrass cover and irrigation on soil mobility and dissipation of metalaxyl and propiconazole. J. Environ. Qual. 30:16121618.

10. Haith, D. A. 2001. TurfPQ, A pesticide runoff model for turf. J. Environ. Qual. 30:10331039. Erratum, Vol. 31.

11. Haith, D. A., and Rossi, F. S. 2003. Risk assessment of pesticide runoff from turf. J. Environ. Qual. 32:447-455.

12. Hong, S., and Smith, A. E. 1997 Potential movement of dithiopyr following application to golf courses. J. Environ. Qual. 26:379-386.
13. Horst, G. L., Shea, P. J., Christians, N., Miller, D. R., Stuefer-Powell, C., and Starrett, S. K 1996. Pesticide dissipation under golf course fairway conditions. Crop Sci. 36:362-370.

14. Mankin, K. R. 2000. An integrated approach for modeling and managing golf course water quality and ecosystem diversity. Ecol. Model. 133:259-267.

15. Marquis, K. 2003. Specially designed wetlands treat golf course runoff. USGA Green Section Record, 41(2):26.

16. Racke, K. D. 2000. Pesticides for turfgrass pest management: Uses and environmental issues. Pages 45-64 in: Fate and Management of Turfgrass Chemicals, J. M. Clark and M. P. Kenna, eds. ASC Symposium Series 743, American Chemical Society, Washington DC.

17. Robbins, P., Polderman, A., and Birkenholz, T. 2001. Lawns and toxins: An ecology of a city. Cities 18:369-380.

18. Smith, A. E., and Bridges, D. C. 1996. Movement of certain herbicides following application to simulated golf course greens and fairways. Crop Sci. 36:1439-1445.

19. Tomlin, C. D. S., ed 1997. The Pesticide Manual: A World Compendium. British Crop Protection Council, Farnham, Surrey, U.K.

20. Vincelli, P. 1999. Gray leaf spot, an emerging disease of perennial ryegrass. Turfgrass Trends 7:1-8.

21. Vincelli, P. 2000. Fungicidal control of gray leaf spot. Golf Course Manage. 68:68-74, 2000.

22. Watschke, T. L., Mumma, R. O., Linde, D. T. Borger, J. A., and Harrison, S. A. 2000. Surface runoff of selected pesticides applied to turf. Pages 94-105 in: Fate and Management of Turfgrass Chemicals, J. M. Clark and M. P. Kenna, eds. ASC Symposium Series 743 , American Chemical Society, Washington DC. $465 \mathrm{pp}$.

23. Williams, D. W., Burrus, P. B., and Vincelli, P. 2001. Severity of gray leaf spot in perennial ryegrass as influenced by mowing height and nitrogen level. Crop Sci. 41:1207-1211. 